\title{
SIMULASI BERBASIS MULTI-AGENT CERDAS UNTUK PEMILIHAN SUPPLIER BERDASARKAN MULTI-ISSUE NEGOTIATION
}

\author{
Demmy Dharma Bhakti
}

\begin{abstract}
ABSTRAK
Seleksi dan evaluasi supplier telah menjadi salah satu topik utama dalam literatur produksi danmanajemen operasi. Pemilihan supplier yang terbaik merupakan proses pengambilan keputusan yang kompleks karena harus dievaluasi dari kriteria-kriteria supplier, dan diperlukan proses tawar menawar antara supplier dan konsumen untuk setiap kriteria yang bisa terdiri dari harga, waktu pengiriman, kualitas, kepercayaan, dan lain-lain, sehingga akan membutuhkan waktu yang lama dan melibatkan kerja kolaburatif antara konsumen dan supplier.Jurnal ini membahas bagaimana membangun model simulasi berbasis multi-agent cerdas yang dapat proses pemilihan supplier berdasarkan multi-issue negotiation.
\end{abstract}

Kata Kunci :Supplier Selection, criteria, Simulationt Game, multiagent.

\section{PENDAHULUAN}

Seperti yang diutarakan Joseph Sarkis dan Srivinas Talluri[1]dalam jurnalnya tentang "A Model for Strategic Supplier Selection", fungsi purchasing untuk beberapa waktu sekarang telah menjadi bagian yang sangat penting dalam manajemen rantai suplai komponen. Hal ini terutama disebabkan oleh dampak signifikan pada keuntungan biaya material, peningkatan investasi di perusahaan manufaktur dan informasi teknologi, dan meningkatnya penekanan pada Just-In-Time(JIT) produksi. Tujuan kritis proses purchasing termasuk mendapatkan produk pada biaya yang tepat dalam jumlah yang tepat dengan kualitas yang tepat pada waktu yang tepat dari sumber yang tepat. Hal tersebut memerlukan keputusan yang efektif menyangkut pelaksanaan seleksi dan evaluasi supplier.

Supplier yang berhubungan langsung dalam proses purchasing merupakan sumber pemenuhan bahan baku produksi yang secara langsung dapat mempengaruhi kelangsungan hidup produksi, karena tanpa adanya supplier maka pemenuhan bahan baku untuk produksi tidak dapat dilakukan dan mengakibatkan berhentinya kegiatan produksi.

Pemilihan supplier yang terbaik merupakan proses pengambilan keputusan yang kompleks karena harus dievaluasi dari kriteria-kriteria supplier[2] (A. Chavez dan P. Maes, 1996), dan diperlukan proses tawar menawar antara supplier dan konsumen untuk setiap kriteria yang bisa terdiri dari harga, waktu pengiriman, kualitas, kepercayaan, dan lain-lain[3] (D. G. Pruitt, 1981), sehingga akan membutuhkan waktu yang lama[4] (Stuart J. Russel dan Peter Norvig, 2003) dan melibatkan kerja kolaburatif antara konsumen dan supplier[5] (J. S. Rosenschein and G. Zlotkin, 1994).

Tujuan utama proses pemilihan supplier adalah untuk mengurangi risiko pembelian, memaksimalkan nilai keseluruhan kepada pembeli, dan mengembangkan kedekatan dan hubungan jangka panjang antara pembeli dan pemasok, yang efektif dalam membantu perusahaan untuk mencapai "Just-InTime" (JIT) produksi [6] (C.C. Li dan Y.P. Fun, 1997). 
Seleksi dan evaluasi supplier telah menjadi salah satu topik utama dalam literatur produksi danmanajemen operasi, terutama dalam teknologi manufaktur dan lingkungan [7] (J. Motwani and M. Youssef, 1999).

Negosiasi adalah proses di mana agentyang bersebrangan memutuskan bagaimana untuk membagi keuntungan darikerjasama[3] (D. G. Pruitt, 1981).Karena keputusan ini dibuat bersama oleh para agent sendiri [8](Kraus, 2001), maka masing-masing agenthanya dapat memperoleh apa yang dipersiapkan oleh agent yang lain untuk mereka. Akan tetapisebelum agent dapat benar-benar melakukan negosiasi seperti itu, mereka harus memutuskan aturan untuk membuat penawaran dan kontra penawaran,yaitu mereka harus mengatur negosiasi protocol[9] (Wooldridge, \& Jennings, 2003).

Dalam proses negosiasi antara konsumen dan supplier terdapat lebih dari satu masalah yang perlu disepakati, seperti harga, waktu pengiriman, kualitas, kehandalan, dan lain sebagainya. Seperti yang diutarakan oleh Shaheen S. Fatima, Michael Wooldridge, dan Nicholas R. Jennings(2006)[10]: "However, in most bilateral negotiations, the parties involved need to settle more than one issue“. Untuk multi-issueNegotiationseperti itu, hasilnya juga tergantung pada satufaktor tambahan, yaitu prosedur negosiasi [11] (Fershtman, 1990) yang menentukanbagaimana masalah akan diselesaikan.

Berdasarkan pada kenyataan seperti yang telah disebutkan di atas, maka masalah yang mendasari pembuatan simulasiini adalah sebagai berikut:

1. Pemilihan supplier membutuhkan kerja kolaboratif antara pembeli dan supplier.

2. Sulit menentukan supplier terbaik berdasarkan banyak pertimbangan kriteria.

\section{LANDASAN TEORI}

\subsection{SIMULASI}

Menurut Roger E Pedersen dalam bukunya yang bejudul Game Design Foundations menjelaskan beberapa genres/kategori game menjadi beberapa bagian antara lain Action Game, Adventure Game, Casual Game, Educational Game, RPG Simulation Game, Sport Game dan Strategy Game.

Game Simulasi merupakan jenis game yang menyatakan keadaan dunia nyata yang disimulasikan dalam bentuk permainan/game sehingga seolah-olah pemain benar-benar menghadapi kenyataan yang sebenarnya.

Game simulasi dibagi atas jenis "Vehicle Simulation" dan "Managing Simulation", dalam Vehicle Simulation pemain memainkan simulasi suatu alat/mesin contohnya : simulasi pesawat terbang, simulasi mengendarai mobil. Managing Simulation merupakan bentuk game dalam memainkan simulasi guna mengatur jalannya kegiatan tertentu,misalnya:simulasi untuk prediksi pasar modal.

\subsection{AGENT DAN MULTIAGENT}

Seperti yang disampaikan Romi [12] menurut Kamus Webster, agent adalah :

1. a person or thing that acts or brings about a certain result

2. one who is empowered to act for another

Dari dua pengertian di atas bisa diartikan bahwa yang pertama,agent mempunyai kemampuan untuk melakukan tugas ataupun pekerjaan tertentu, kemudian pada pengertian yang kedua dapat kita pahami bahwa agent melakukan tugas atau pekerjaan dalam kapasitas untuk sesuatu atau untuk orang lain.

Multi Agent System (MAS) yaitu suatu agent cerdas yang bisa berinteraksi dan berkolaborasi satu dengan yang lain untuk mengerjakan suatu tugas (job) tertentu.

Caglayan [1] mendefinisikan software agent sebagai: 
"Suatu entitas software komputer yang memungkinkan user (pengguna) untuk mendelegasikan tugas kepadanya secara mandiri (autonomously)."

Salah satu contoh aplikasi software agent adalah sebuah software yang dikembangkan oleh Chavez and Maes [2] yang menjelaskan tentang Pasar Elektronik yang disebut "Kasbah". Software ini dibangun sesuai lingkungan pasar dimana dibuat "Pembeli" dan "Penjual" yang terlibat dalam negosiasi proses jual beli secara elektronik dengan menggunakan Intelligent Agent.

Menurut Maes kegunaan software agentadalah :

"under certain conditions, an interface agent can "program itself" (i.e., it can acquire the knowledge it needs to assist its user). The agent is given a minimum of background knowledge, and it learns appropriate "behavior" from the user and from other agents" [2].

Dari definisi kegunaan agent di atas dapat dipelajari bahwa agent harus memiliki kemampuan untuk berinteraksi dengan agent yang lain dan user sehinggaagent dapat membantu user dalam menghadapi segala permasalahannya.

Sedangkan Menurut Jennings [9]software agent dengan autonomous agent digunakan sebagai pencarian, pengintaian, pengendalian termasuk untuk negosiasi. Kemudian Menurut Yuan dan Turrel [13] Software agent dalam bentuk negosiasi elektronik bisa memberikan bantuan bahkan bisa mengganti peran negosiator dan fasilitator.

Menurut Romi Satria Wahono [12] dalam papernya tentang "Pengantar Software Agent" Karakteristik dan Atribut software agent meliputi :

\section{Autonomy:}

Artinya Agent dapat melakukan tugas secara mandiri(autonomus) dan tidak dipengaruhi secara langsung oleh user, agent lain ataupun oleh lingkungan (environment).
2.Intelligence, Reasoning, dan Learning:

Setiap agent harus mempunyai beberapa faktor yang bisa mengidentifikasikan dirinya sebagai agent yaitu intelegensi (intelligence). Jika kita membahas tentang intelligence, ada tiga komponen yang harus dimiliki yaitu: internal knowledge base, kemampuan reasoning berdasar pada knowledge base yang dimiliki, dan kemampuan learning untuk beradaptasi dalam perubahan lingkungan.

\section{Mobility dan Stationary:}

Agent dengan bentuk mobile agent harus mempunyai kemampuan yang merupakan karakteristik tertinggi yang dia miliki yaitu mobilitas. Artinya agent tersebut harus bisa digunakan dalam berbagai tempat yang berbeda secara baik.

\section{Delegation:}

Sesuai dengan tugas utama dari agent yaitu sesuai dengan definisi agent bergerak dalam kerangka menjalankan tugas yang diperintahkan oleh user. pendelegasian (delegation) merupakan karakteristik utama yang harus dimiliki oleh agent.

\section{Reactivity:}

Karakteristik agent yang lain adalah kemampuan untuk bisa cepat beradaptasi dengan adanya perubahan informasi yang ada dalam suatu lingkungan (environment). Lingkungan itu bisa mencakup: agent lain, user, adanya informasi dari luar.

\section{Proactivity dan Goal-Oriented:}

Sifat proactivity boleh dikata adalah kelanjutan dari sifat reactivity. Agent tidak hanya dituntut bisa beradaptasi terhadap perubahan lingkungan, tetapi juga harus mengambil inisiatif langkah penyelesaian apa yang harus diambil. Untuk itu agent harus 
didesain memiliki tujuan (goal) yang jelas, dan selalu berorientasi kepada tujuan yang diembannya (goal-oriented).

\section{Communication and Coordination} Capability:

Agent harus memiliki kemampuan berkomunikasi dengan user dan agent yang lain.

\subsection{Negosiasi dan Multi-Issue Negotiation}

Negosiasi adalah proses di mana agentyang bersebrangan memutuskan bagaimana untuk membagi keuntungan darikerjasama[8].Karena keputusan ini dibuat bersama oleh para agent sendiri, maka masing-masing agenthanya dapat memperoleh apa yang dipersiapkan oleh agent yang lain untuk mereka. Akan tetapisebelum agent dapat benar-benar melakukan negosiasi seperti itu, mereka harus memutuskan aturan untuk membuat penawaran dan kontra penawaran,yaitu mereka harus mengatur negosiasi protokol.

Dalam papernya tentang "Multiagent compromise via negoitation" Sycara [14] menyatakan bahwa proses negosiasi melalui agent cerdas meliputi pengidentifikasian potensi untuk berinteraksi dari setiap agent cerdas melalui pengembangan kemampuan berkomunikasi atau penalaran terhadap kondisi terkini atau perubahan dari keinginan para agen lain dalam sistem sehingga dapat dipergunakan untuk menciptakan sesuatu yang lebih korporatif.

Seperti yang diutarakan oleh Shaheen S. Fatima, Michael Wooldridge, dan Nicholas R. Jennings(2006): "However, in most bilateral negotiations, the parties involved need to settle more than one issue". Hal seperti disebutkan di atas disebut sebagai multi-issue negotiation. Untuk multi-issueNegotiationseperti itu, hasilnya juga tergantung pada satufaktor tambahan, yaitu prosedur negosiasi yang menentukanbagaimana masalah akan diselesaikan.

Secara garis besar, ada tiga cara untuk menyelesaikan multi-issue negotiation, yaitu:

1.Package deal: Pendekatan ini menggabungkan semua masalah dan membahas mereka bersama sebagai satu buah paket.

2.Simultaneous negotiation: Ini melibatkan penyelesaian masalah secara bersamaan, namun secara independen, satu sama lain.

3. Sequential negotiation: negosiasi ini melibatkan isu-isu secara berurutan, satu demi satu.

\subsection{Pemilihan SupPlier}

Menurut Kamus Besar Bahasa Indonesia yang disediakan oleh Pusat Bahasa Departemen Nasional RI, pemilihan bisa diartikan sebagai suatu proses atau caraatau perbuatan memilih.

Sedangkan supplier atau pemasok adalah orang atau organisasi yang membayar pajak atau mengadakan persediaan atau memberikan suplai.

Jadi pemilihan supplier adalah suatu proses yang dilakukan untuk memilih orang atau organisasi yang mengadakan persediaan atau memberikan suplai.

Supplier yang berhubungan langsung dalam proses purchasing merupakan sumber pemenuhan bahan baku produksi yang secara langsung dapat mempengaruhi kelangsungan hidup produksi, karena tanpa adanya supplier maka pemenuhan bahan baku untuk produksi tidak dapat dilakukan dan mengakibatkan berhentinya kegiatan produksi.

Pemilihan supplier diselenggarakan dengan maksud untuk mencari dan menyeleksi supplier terbaik dalam pengadaan barang, mengingat betapa pentingnya fungsi supplier yang merupakan sumber pemenuhan bahan baku produksi yang secara langsung dapat mempengaruhi kelangsungan hidup produksi, karena tanpa adanya supplier 
maka pemenuhan bahan baku untuk produksi tidak dapat dilakukan dan mengakibatkan berhentinya kegiatan produksi.

Pemilihan supplier yang terbaik merupakan proses pengambilan keputusan yang kompleks karena harus dievaluasi dari kriteria-kriteria supplier[2], dan diperlukan proses tawar menawar antara supplier dan konsumen untuk setiap kriteria yang bisa terdiri dari harga, waktu pengiriman, kualitas, kepercayaan, dan lain-lain[3], sehingga akan membutuhkan waktu yang lama[4] dan melibatkan kerja kolaburatif antara konsumen dan supplier[5].

\section{ANALISIS SISTEM}

Permasalahan utama yang dihadapi pada proses pemilihan supplier adalah sangat sulitnya koordinasi banyak pihak (entitas) dikarenakan masing-masing pihak (entitas) memiliki kepentingan yang tidak jarang saling bertabrakan dan seringkali mereka berupaya untuk memaksimalkan keuntungannya sendiri.

Akibat adanya konflik kepentingan inilah perlu dicari suatu kesepakatan di antara setiap pihak yang terlibat, dalam hal ini adalah konsumen dan supplier. Negosiasi adalah suatu cara yang dipilih untuk mencapai kesepakatan tersebut, namun proses negosiasi yang biasa terjadi adalah bertemunya negosiator kedua belah pihak, dimana proses seperti ini membutuhkan waktu dan biaya yang tidak sedikit.

Dengan permasalahan di atas diperlukan otomatisasi negosiasi dan penilaian sehingga kesepakatan dapat dicapai dengan cepat, efisien serta tidak bersifat subjektif.

\section{A. Model Use-case Simulasi Pemilihan Supplier}

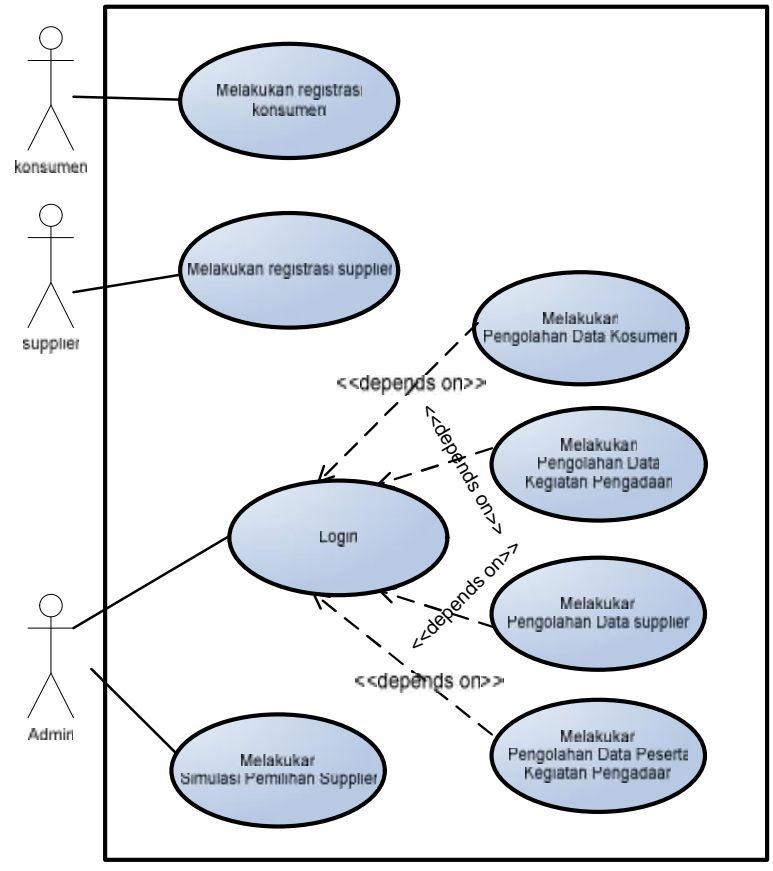

Gambar 1Use-case diagram

naratif use-case :

- Use-case Registrasi Konsumen

Proses registrasi konsumen yang akan mengadakan kegiatan pengadaan. Konsumen akan memberikan biodata konsumen beserta kegiatan pengadaan yang akan dilaksanakan lengkap dengan data-data kriteria kegiatan, dimana seluruh data tersebut diserahkan

- Use-case Registrasi Supplier

Proses registrasi supplier yang akan mengikuti kegiatan pengadaan yang sudah didaftarkan oleh konsumen melalui Admin. Supplierakan memberikan biodata supplier beserta kegiatan pengadaan yang akan diikutinya lengkap dengan data-data kriteria kegiatan, dimana seluruh data tersebut diserahkan kepada Admin.

- Use-case Login

Proses Login merupakan otentifikasi pengguna/admin dari simulasi pemilihan supplier. Untuk melakukan pengolahan data pada simulasi maka admin harus melakukan proses login terlebh 
dahulu dengan memasukkan username dan password.

- Use-case Pengolahan Data

\section{Konsumen}

Proses pengolahan data konsumen dilakukan oleh Admin berdasarkan biodata konsumen yang diberikan oleh konsumen pada saat registrasi.

- Use-case Pengolahan Data Kegiatan

Pengadaan

Proses pengolahan data kegiatan pengadaan dilakukan oleh Admin berdasarkan data-data kegiatan pengadaan yang diberikan oleh konsumen pada saat proses registrasi konsumen.

- Use-case Pengolahan Data Supplier

Proses pengolahan data supplier dilakukan oleh Admin berdasarkan biodata supplier yang diberikan oleh supplier pada saat proses registrasi.

- Use-case Pengolahan Data Peserta

Kegiatan Pengadaan

Proses pengolahan data peserta kegiatan pengadaan dilakukan oleh Admin berdasarkan data-data kegiatan pengadaan yang akan diikuti oleh supplier pada saat proses registrasi supplier.

- Use-case Simulasi Pemilihan

\section{Supplier}

Proses simulasi pemilihan supplier berdasarkan data-data konsumen, kegiatan pengadaan, supplier, dan peserta kegiatan pengadaan yang sudah dimasukkan oleh Admin.

B. Desain Arsitektur IA dan Rule Base Simulasi



Gambar 2 di atas menunjukan desan arsitektur Intelligent Agent Processing. Dimulai dengan adanya input yang masuk ke dalam proses. Terdapat 3 agent yang berperan di dalam proses intelligent sendiri, yaitu Consumer agent, Supplier agent dan Facilitator agent. Fungsi dari Facilitator agent adalah untuk memfasilitasi proses negosiasi antara Consumer agent dan Supplier agent, dimana Facilitator agentakan selalu mendengarkan (listening) pesan/message dari Consumer agent maupun Supplier agent yang kemudian akan diproses dalam kegiatan negosiasi. Di dalam proses negosiasi terdapat dua status yang dipergunakan yaitu request (dari supplier) dan offer (dari consumer) yang akan berkolaborasi untuk mencapai kesepakatan berdasarkan rulebase yang telah ditetapkan. Hasil dari proses negosiasi sendiri terdiri dari dua status , yaitu accepted(diterima) dan rejected (ditolak). Status accepted akan muncul ketika penawaran dari salah satu agent sesuai dengan ambang batas dari agent yang lain, sedangkan status rejected akan muncul apabila penawaran dari salah satu agent melebihi atau kurang dari ambang batas agent yang lain.

Di dalam rulebase pemilihan supplier ini terdapat tiga isu yang dijadikan sebagai dasar negosiasi antara Consumer agent danSupplier agent, yaitu :

- Harga

- Kwalitas

- Waktu pengiriman

- garansi

Proses negosiasi antara Consumer agent dan Supplier agent akan menggunakan pendekatan Package deal,yaitu dengan menggabungkan harga, kwalitas, waktu pengiriman, dan kepercayaan serta membahas mereka bersama sebagai satu buah paket

Gambar 2 Desain Arsitektur IA 


\section{Diagram Aktifitas Pemilihan Supplier}

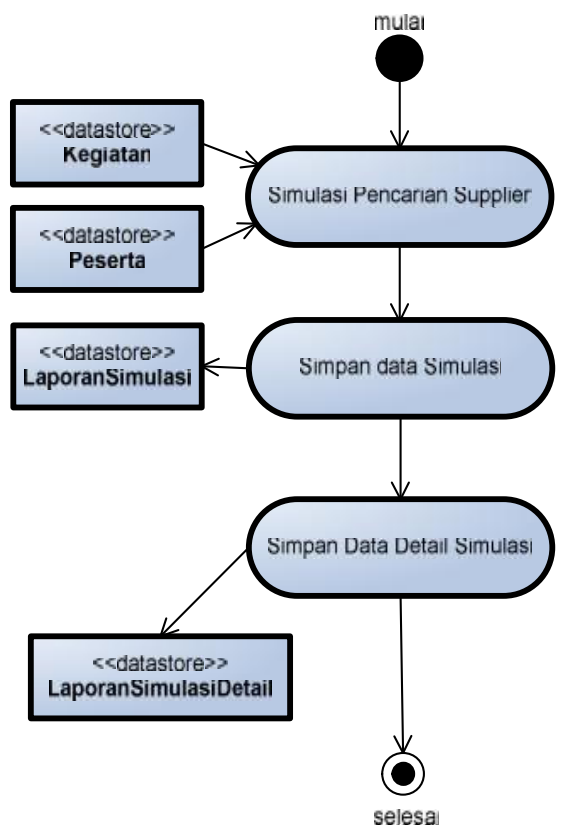

Gambar 3 Diagram Aktifitas Pemilihan Supplier

Pada Gambar 3 di atas menggambarkan activity diagram dari simulasi pemilihan supplier. Pertamatama simulasi pemilihan supplier akan mengambil semua data kegiatan dan peserta kegiatan yang terdapat pada datastore Kegiatan dan Peserta, semua data yang diambil tersebut dijadikan data dasar simulasi untuk mencari supplier terbaik. Proses simulasi dilakukan dengan menggunakan arsitektur IA seperti dijelaskan di atas. Setelah proses simulasi selesai maka seluruh data hasil proses simulasi akan disimpan pada datastore LaporanSimulasi dan LaporanSimulasiDetail. Penyimpanan data hasil simulasi dimaksudkan agar hasil dari proses simulasi dapat ditampilkan kembali dan menjadi informasi yang bermanfaat bagi fihakfihak terkait di masa yang akan datang. Salah satu dari isu yang diangkat pada proses simulasi pemilihan supplier adalah garansi, data-data hasil simulasi sebelumnya dapat dimanfaatkan sebagai dasar perbandingan supplier.
Relasi Antar Table

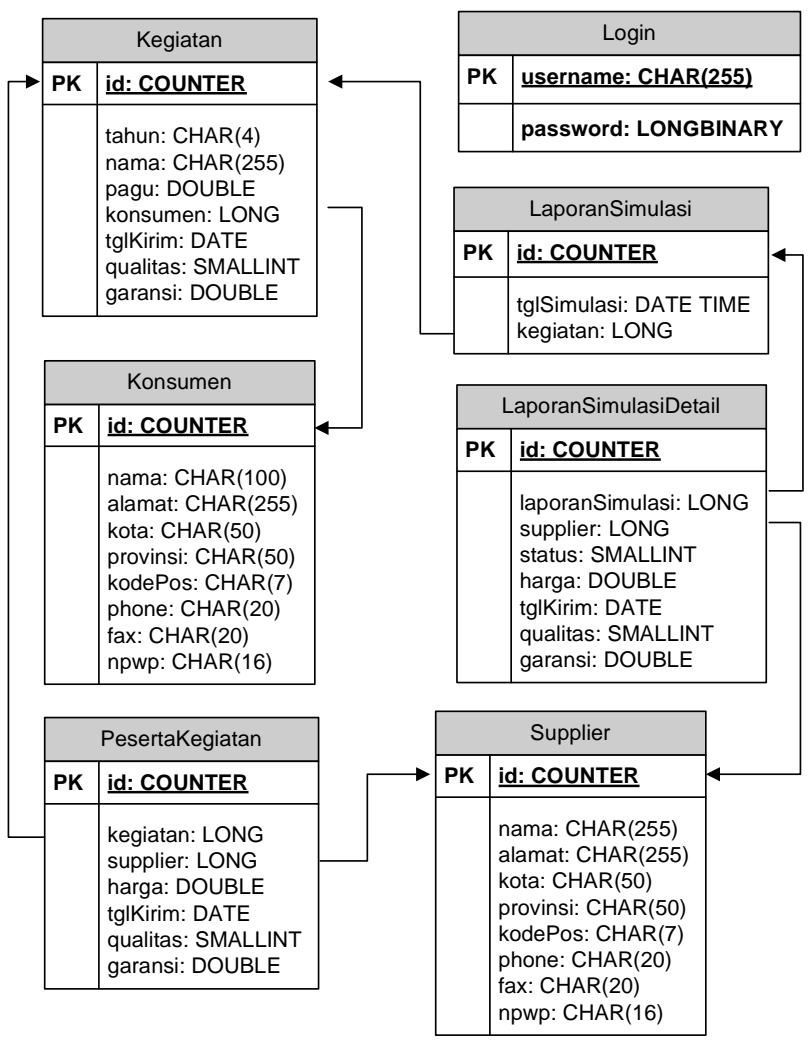

Gambar 4 relasi antar tabel simulasi pemilihan supplier

Terdapat 7 (tujuh) buah tabel yang dipergunakan dalam proses simulasi ini, yaitu :

- Login

- Konsumen

- Supplier

- Kegiatan

- PesertaKegiatan

- Laporan simulasi

- Laporansimulasidetail

\section{Pengukuran Simulasi}

Untuk mengukur ketepatan dari hasil simulasi yang sudah dilakukan, dipergunakan precission and recall.

Precissionmerupakan salah satu ukuran dari efektivitas beberapa aplikasi komputer untuk mencari kata-kata, memilih seorang calon danatau item lainnya.Precission adalah ukuran dari proporsi hasil dari aplikasi komputer yang dianggap relevan atau benar. 
Recall merupakan salah satu ukuran efektivitas beberapa aplikasi komputer untuk mencari kata-kata pencarian, istilah calon, dan item lainnya. Recall adalah ukuran dari proporsi dari semua kemungkinan hasil yang benar dari aplikasi komputer yang benar-benar menghasilkan.

Precission dapat dilihat sebagai ukuran ketepatan atau kualitas, sedangkan Recall adalah ukuran dari kelengkapan atau kuantitas. Dalam istilah sederhana, Recall yang tinggi berarti algoritma mengembalikan sebagian besar hasil yang relevan, sementara Precission tinggi berarti bahwa algoritma mengembalikan hasil yang secara substansial lebih relevan daripada tidak relevan.

Untuk klasifikasi pada Precission andRecall dipergunakan istilah-istilah true positive, true negative, false positive, dan false negative. Istilah-istilah tersebut untuk membandingkan hasil yang diuji dengan penilaian eksternal yang dipercaya. Istilah positif dan negatif mengacu pada prediksi (kadang-kadang dikenal sebagai harapan), dan istilah benar dan salah lihat apakah prediksi sesuai dengan penilaian eksternal (kadang-kadang dikenal sebagai pengamatan). Hal ini digambarkan oleh tabel di bawah ini:

Table 1 ilustrasi istilah Precission and

\begin{tabular}{|c|c|c|}
\hline \multicolumn{3}{|c|}{ Recall } \\
\hline & \multicolumn{2}{|c|}{$\begin{array}{l}\text { actual class } \\
\text { (observation) }\end{array}$} \\
\hline \multirow{2}{*}{$\begin{array}{l}\text { predicted } \\
\text { class } \\
\text { (expectation) }\end{array}$} & \begin{tabular}{|l}
\multicolumn{1}{c}{ tp } \\
(true \\
positive) \\
Correct \\
result \\
\end{tabular} & $\begin{array}{l}\text { fp } \\
\text { (false positive) } \\
\text { Unexpected } \\
\text { result }\end{array}$ \\
\hline & \begin{tabular}{|l}
\multicolumn{1}{|c}{$\mathbf{f n}$} \\
(false \\
negative) \\
Missing \\
result
\end{tabular} & \begin{tabular}{|l}
\multicolumn{1}{|}{$\mathbf{n}$} \\
(true negative) \\
Correct \\
absence of \\
result
\end{tabular} \\
\hline
\end{tabular}

Kemudian Precision and recall didefinisikan dengan:

$$
\begin{gathered}
\text { Precision }=\frac{t p}{t p+f p} \\
\text { Recall }=\frac{t p}{t p+f n}
\end{gathered}
$$

Recall pada kontek ini juga direferensikan pada nilai True Positive atau Sensitivity, dan precision direferensikan kepada nilai prediksi positip (Positive predictive value/PPV). Pengukuran lain yang berkaitan adalah nilai True Negative and Accuracy. Nilai True Negative disebut juga sebagai Specificity.

$$
\begin{aligned}
& \text { True negative rate }=\frac{t n}{t n+f p} \\
& \text { Accuracy }-\frac{t_{p}+t_{x t}}{t_{p}+t n+f p+f n}
\end{aligned}
$$

Proses pengujian implementasi simulasi pemilihan supplier dengan multi agen cerdas dilakukan dengan cara melakukan proses simulasi dengan mengisikan data konsumen sebanyak dua (2) konsumen yang akan mengadakan kegiatan, data kegiatan pengadaan sebanyak sepuluh (10) kegiatan yang akan disimulasikan dengan supplier sebanyak dua puluh (20) buah perusahaan yang terbagi ke dalam kegiatan untuk saling bernegosiasi dalam mencapai kesepakatan untuk masing-masing kegiatan, dengan hasil sebagai berikut :

Tabel 2 hasil pengujian simulasi

\begin{tabular}{|l|l|l|l|}
\hline $\begin{array}{l}\text { ke } \\
\mathrm{g}\end{array}$ & Peserta & $\begin{array}{l}\text { Harapan } \\
\text { peserta } \\
\text { diterima }\end{array}$ & $\begin{array}{l}\text { Hasil } \\
\text { Simulasi }\end{array}$ \\
\hline 1 & $\begin{array}{l}5 \text { peserta }(\mathrm{A}, \\
\mathrm{E}, \mathrm{F}, \mathrm{J}, \mathrm{N})\end{array}$ & 4 & 4 \\
\hline 2 & $\begin{array}{l}3 \text { peserta (D, } \\
\text { H, K) }\end{array}$ & 3 & 3 \\
\hline 3 & $\begin{array}{l}2 \text { peserta (B, } \\
\text { O) }\end{array}$ & 2 & 3 \\
\hline 4 & $\begin{array}{l}4 \text { peserta }(\mathrm{C}, \\
\mathrm{I}, \mathrm{L}, \mathrm{M})\end{array}$ & 2 & 2 \\
\hline 5 & $\begin{array}{l}3 \text { peserta }(\mathrm{G}, \\
\mathrm{H}, \mathrm{K})\end{array}$ & 1 & 1 \\
\hline 6 & 5 peserta & 3 & 3 \\
\hline
\end{tabular}




\begin{tabular}{|l|l|l|l|}
\hline 7 & 2 peserta & 2 & 2 \\
\hline 8 & 4 peserta & 4 & 4 \\
\hline 9 & 5 peserta & 3 & 3 \\
\hline 10 & 4 peserta & 3 & 3 \\
\hline
\end{tabular}

Dari hasil pengujian simulasi maka didapat perhitungan sebagai berikut:

Tabel 3 Perbandingan Simulasi

\begin{tabular}{|c|c|c|}
\hline & \multicolumn{2}{|c|}{$\begin{array}{c}\text { Sistem } \\
\text { (observation) }\end{array}$} \\
\hline \hline & tp & fp \\
predicted class & 27 & 2 \\
\hline (expectation) & fn & tn \\
& 1 & 10 \\
\hline
\end{tabular}

Dari table di atas maka di dapat perhitungan:

$$
\begin{gathered}
\text { Precission }=\frac{t p}{t p+f p}=\frac{27}{27+2}=\frac{27}{29} \\
=0,93=93 \% \\
\text { Recall }=\frac{t p}{t p+f n}=\frac{27}{27+1}=\frac{27}{28} \\
=0,96=96 \% \\
\text { Specifity }=\frac{t n}{t n+f p}=\frac{10}{10+2}=\frac{10}{12} \\
=0,83=83 \% \\
\text { Accuracy }=\frac{t p+t n}{t p+t n+f p+f n} \\
=\frac{27+10}{27+10+2+1} \\
=\frac{37}{40}=0,93=93 \%
\end{gathered}
$$

\section{KESIMPULAN}

Berdasarkan hasil pengujian simulasi pemilihan supplier terbaik berbasis multiagen cerdas maka dapat diambil kesimpulan:

1) Simulasi pemilihan supplier mampu meminimalkan partisipasi aktif dari konsumen maupun supplier.

2) Simulasi pemilihan supplier terbaik berbasis multiagen cerdas dengan multi kriteria mampu memberikan hasil secara otomatis dalam proses negosiasi.

\section{DAFTAR PUSTAKA}

Joseph Sarkis, Srivinas Talluri, "A Model for Strategic Supplier Selection", Journal of Supply Chain Management Volume 38 Issue 1, Pages $18-28$.

A. Chavez and P. Maes, "Kasbah: An Agent Marketplace for Buying and Selling Goods", Proceedings of the First International Conference on the Practical Application of Intelligent Agents and Multi-Agent Technology (PAAM-96), pp. 75-90, London, UK, 1996.

D. G. Pruitt, "Negotiation Behaviour", Academic Press, 1981.

Stuart J. Russel, Peter Norvig, "Artificial Intelligent: A Modern Approach (2nd ed.)", Upper Saddle River, NJ: Prentice Hall, ISBN 0-13-790395-2, http://aima.cs.berkeley.edu/, chpt. 2, 2003.

H. Raiffa, "The Art and Science of Negotiation", Harvard University Press, Cambridge, USA, 1982.

C.C. Li and Y.P. Fun, "A new measure for supplier performance evaluation", IIE Transactions, 29(1):753-758, 1997.

J. Motwani and M. Youssef, "Supplier Selection In Developing Countries: A Model Development", Emerald, 10(13): 154-162, 1999. 
S. Krauss, "Strategic Negotiation in Multi-agent Environments", The MIT Press, Cambridge, Massachusetts, 2001.

Michael J Wolldridge,Nicholas R. Jennings, "Agent

Theories,Archithecture and Languages : A Survey", London UK, 2002.

Shaheen S. Fatima, Michael Wooldridge, Nicholas R. Jennings, "Multi-Issue Negotiation with Deadlines", Journal of Artificial Intelligence Research 27 (2006) 381-417.

C. Fershtman, "The Importance of the Agenda in Bargaining", Games and Economic Behavior, 2, 224-238, 1990.

Romi Satria Wahono, Pengantar Software Agent: Teori dan Aplikasi, Proceedings of the IECI Japan Workshop 2001 (IJW-2001), Invited Paper, pp. 04-21, Tokyo, Japan, March 2001.

Yuan Y., and Turel, O, "A Business Model for e-negotiation in Elektronic Commerce", IntNeg Working Paper INR02/04, John Molson School of Business, Concordia University, Montreal,Quebec,Canada, 2004.

K. Decker, A. Pannu, K. Sycara, and M. Williamson, "Designing Behaviors for Information Agents", Proceedings of the First International Conference on Autonomous Agents (Agents-97), pp. 404-412,Marina del Rey, CA, February 1997. 